University of New Orleans

ScholarWorks@UNO

$11-2010$

\title{
William Carlos Williams, David Raphael Wang, and the Dynamic of East/West Collaboration
}

Zhaoming Qian

University of New Orleans, zqian@uno.edu

Follow this and additional works at: https://scholarworks.uno.edu/engl_facpubs

Part of the Literature in English, North America Commons

\section{Recommended Citation}

Qian, Zhaoming. "William Carlos Williams, David Raphael Wang, and the Dynamic of East/West Collaboration." Modern Philology 108.2 (Nov 2010): 304-21.

This Article is brought to you for free and open access by the Department of English and Foreign Languages at ScholarWorks@UNO. It has been accepted for inclusion in English Faculty Publications by an authorized administrator of ScholarWorks@UNO. For more information, please contact scholarworks@uno.edu. 
William Carlos Williams, David Raphael Wang, and the Dynamic of East/West Collaboration Author(s): Zhaoming Qian

Source: Modern Philology, Vol. 108, No. 2 (November 2010), pp. 304-321

Published by: The University of Chicago Press

Stable URL: http://www.jstor.org/stable/10.1086/657363

Accessed: 05/04/2011 10:29

Your use of the JSTOR archive indicates your acceptance of JSTOR's Terms and Conditions of Use, available at http://www.jstor.org/page/info/about/policies/terms.jsp. JSTOR's Terms and Conditions of Use provides, in part, that unless you have obtained prior permission, you may not download an entire issue of a journal or multiple copies of articles, and you may use content in the JSTOR archive only for your personal, non-commercial use.

Please contact the publisher regarding any further use of this work. Publisher contact information may be obtained at http://www.jstor.org/action/showPublisher?publisherCode=ucpress.

Each copy of any part of a JSTOR transmission must contain the same copyright notice that appears on the screen or printed page of such transmission.

JSTOR is a not-for-profit service that helps scholars, researchers, and students discover, use, and build upon a wide range of content in a trusted digital archive. We use information technology and tools to increase productivity and facilitate new forms of scholarship. For more information about JSTOR, please contact support@jstor.org.

The University of Chicago Press is collaborating with JSTOR to digitize, preserve and extend access to Modern Philology. 


\title{
William Carlos Williams, David Raphael Wang, and the Dynamic of East/West Collaboration
}

\author{
ZHAOMING QIAN \\ University of New Orleans and Hangzhou Normal University
}

Originating from a collaborative translation project, "The Cassia Tree" by William Carlos Williams (1883-1963) and David Raphael Wang (1931-77) was not issued until three years after Williams's death. ${ }^{1}$ The thiry-ninepoem series fared noticeably less well than comparable endeavors by the collaborators' peers. Reviewing it for the William Carlos Williams Review, Stephen Field calls attention to the success of Gary Snyder's 1958 sequence "Cold Mountain Poems," evidenced by its entry into Cyril Birch's Anthology of Chinese Literature (1965). ${ }^{2}$ By contrast, none of the "Cassia Tree" poems has been reprinted anywhere except in volume 2 of The Collected Poems of William Carlos Williams (1988). ${ }^{3}$ Field attributes the scholarly indifference partly to Williams's "virtual silence on the subject of China" and partly to the questionable quality of "what were supposedly his Chinese translations." "As translations," Field notes, these poems "simply cannot stand up to close scrutiny." 4

But was "The Cassia Tree" intended to be a collection of faithful translations? In a headnote Wang designated these poems not as "translations in the sense that Arthur Waley's versions are translations" but rather as "re-creations in the American idiom-a principle to which William Carlos Williams dedicated his poetic career." ${ }^{5}$ The key word here is re-creations. As a sequence of re-creations from the Chinese, "The Cassia Tree"

1. David Raphael Wang, "The Cassia Tree," New Directions 19 (1966): 211-31.

2. Stephen Field, “'The Cassia Tree': A Chinese Macropoem," William Carlos Williams Review 18 (1992): 34-49.

3. See Christopher MacGowan, ed., The Collected Poems of William Carlos Williams, vol. 2 (New York: New Directions, 1988), 359-76, plus note, 500-502. Further references to this volume will be given parenthetically as $C P 2$.

4. Field, "Chinese Macropoem," 34.

5. Wang, "Cassia Tree," 211. In The Scandals of Translation: Towards an Ethics of Difference (New York: Routledge, 1998), Lawrence Venuti calls "an original composition" based on a translated text "pseudotranslation" (33).

(C) 2010 by The University of Chicago. All rights reserved. 0026-8232/2010/10802-0006 $\$ 10.00$ 
can be related to Ezra Pound's Cathay (1915), a chief example of what Yunte Huang terms "intertextual travel." Drawing on Stephen Greenblatt, Lisa Lowe, and others, Huang identifies America's imaging of Asia as a process of transpacific "intertextual travel" "driven in particular by the writers' desire to appropriate, capture, mimic, parody, or revise the Other's signifying practices." Cathay as re-created "from the notes of the late Ernest Fenollosa" has little chance of appearing in textbooks for undergraduate courses in Chinese literature. ${ }^{7}$ However, the Cathay poems "The River-merchant's Wife" and "Lament of the Frontier Guard" have entered The Norton Anthology of American Literature and The Norton Anthology of Modern and Contemporary Poetry. ${ }^{8}$ Their place there is well deserved. For Huang and the New Americanists, the expansion of the American literary canon is "unthinkable without taking into account its intercultural, intertextual appropriations." 9

"Intertextual travel," to quote Huang, involves "a process in which multiple readings of the 'original' are reduced to a version that foregrounds the translator's own agenda." ${ }^{10}$ Imagism and antiwar polemic are two of Pound's campaigns swaying the inventive procedure of Cathay. What might be at work influencing the making of "The Cassia Tree"? What roles did Williams and Wang each play in the project? And what does this case reveal to us about the dynamic of East/West collaboration?

In this essay, I approach these questions by examining the creative process of this neglected case of "intertextual travel." The series was hardly the first modernist enterprise that involved a Chinese collaborator. In their late careers Williams's friends Ezra Pound and Marianne Moore also collaborated with intellectuals from China for inspiration. ${ }^{11}$ Whereas Achilles Fang inspired Pound with Confucian ideas that govern the Rock-Drill cantos (1955), Mai-mai Sze was, in Moore's own words, re-

6. Yunte Huang, Transpacific Displacement: Ethnography, Translation, and Intertextual Travel in Twentieth-Century American Literature (Berkeley: University of California Press, 2002), 3. See also Stephen Greenblatt, Marvelous Possessions: The Wonder of the New World (University of Chicago Press, 1991); and Lisa Lowe, Immigrant Acts: On Asian American Cultural Politics (Durham, NC: Duke University Press, 1996).

7. For Cathay, see Lea Baechler and A. Walton Litz, eds., Personae: The Shorter Poems of Ezra Pound (New York: New Directions, 1990), 129-46, quotation on 130.

8. See Nina Baym et al., eds., The Norton Anthology of American Literature, 5 vols. (New York: Norton, 2003), D:1286; Jahan Ramazani, Richard Ellmann, and Robert O'Clair, eds., The Norton Anthology of Modern and Contemporary Poetry, 2 vols. (New York: Norton, 2003), $1: 352-53$.

9. Huang, Transpacific Displacement, 186.

10. Ibid., 4.

11. Here I follow Thomas Inge's broader sense of collaboration: "Anytime another hand enters into an effort, a kind of collaboration occurs" ("Collaboration and Concepts of Authorship," PMLA 116 [2001]: 629). 
sponsible for "the celestial reveries" of O to Be a Dragon (1959). ${ }^{12}$ The Williams-Wang undertaking is best viewed along with these instances in the context of transpacific literary exchange. In refashioning China for American literature, the two partners were pulled by conflicting desires-to be modernist, and to be Chinese. Despite its actual assimilation of Chinese images, themes, and styles, "The Cassia Tree" signals a commitment to modernist values, particularly Williams's poetic of 1916-30 that emphasizes both the American idiom and a minimal, spatial design. I hope to suggest that the collaborative project was ultimately instrumental in the older poet's restoration of minimalism in his last book, Pictures from Brueghel (1962).

Williams first discovered Wang's promise as a poet-translator when going over the February 1957 Edge. Writing to Pound at Washington's St. Elizabeths Hospital, Williams praised Wang's eight classic Chinese poems printed in the Poundian journal: "I do enjoy EDGE- the last translations from the chink by/of David Rafael Wang are worth the trip half way round the world to have encountered." 13 The letter prompted Pound to encourage Wang to contact his old pal for whatever professional help he himself was not able to give. A 1949 immigrant from China, Wang attended La Scuola Italiana of Middlebury before completing a BA degree in English at Dartmouth College in 1955. After writing poetry in the shadow of Pound for several years, he was attracted to Pound and his followers at St. Elizabeths Hospital. It was at Pound's suggestion that Wang submitted his Chinese translations to the Edge. Williams's enthusiasm for the then novice poet is evident in his reply of March 16, 1957:

For heaven's sake! I've been looking for you everywhere since I read those Chinese translations in the last EDGE. Pound wrote me one of his unnecessarily cryptic cards telling me you were in New York. I thought you were merely passing through the city. Now I find out that you are a friend of Gil Sorrentino.

12. Much of what Pound and Achilles Fang discussed in their 1950-55 correspondence (Beinecke Library, Yale University) found its way into the Rock-Drill cantos. Marianne Moore to Mai-mai Sze, April 18, 1959, Rosenbach Museum and Library, Philadelphia, quoted in Zhaoming Qian, The Modernist Response to Chinese Art: Pound, Moore, Stevens (Charlottesville: University of Virginia Press, 2003), 181.

13. William Carlos Williams to Ezra Pound, February 1957, Beinecke Library, Yale University. In addition, the Beinecke Library has twenty-four letters from David Wang to William Carlos Williams. Eleven letters and three cards from William Carlos Williams and Florence Williams to David Wang are housed in the Rauner Special Collections of Dartmouth College. In further references, these items will be cited parenthetically as Beinecke: Wang-Williams or Rauner: Williams-Wang. For an account of the Pound/Wang relationship, see Hugh Witemeyer, "The Strange Progress of David Hsin-fu Wand [Wang]," Paideuma 15 (1986): 191-209. 
Of course come out and see us. It will have to be after the middle of next week-if you will be free. Come in the afternoon unless you are not free then when you can make it Saturday or Sunday. I'm not much good evenings. Let me hear from you. I'm awfully glad you wrote. (Rauner: Williams-Wang)

Six months after their first meeting, Wang brought up the idea of working together on a group of Chinese poems. At that time Williams was finishing Paterson 5. In a letter dated September 28, 1957, he accepted Wang's proposal: "I am fascinated by the prospect of working with you on the Chinese translation-and we will of course do it together and soon but not now." In that letter he also suggested making a book out of the collaboration: "I am anxious that a book should come of it. . . Talk to David McDowell of McDowell, Obolensky, Inc., 219 E 61. I have engaged myself to let him publish any book I shall write from this point forward" (Rauner: Williams-Wang).

David Wang had his own motivations for the project. First, the undertaking would provide a once-in-a-lifetime opportunity to study creative writing with a leading modernist poet. Second, whatever result came of it was likely to send him on the way to an illustrious career. But why should Williams, in his old age and with other commitments, have been interested in taking up this enterprise?

Chinese poetry had always been one of Williams's preoccupations. In April 1915 he was among the first to praise Pound's Cathay, calling it "something of great worth well handled." ${ }^{14}$ Under the impact of Cathay, Williams engaged in an extended dialogue with Chinese poets through translations, whose effects are manifest in "Complete Destruction," "The Red Wheelbarrow," and "The Locust Tree in Flower." 15 Thirty years after these 1920s experiments, Williams was eager to embrace this partnership, which he thought offered "an acquaintance with the great poets of China through one of their direct descendents" (Rauner: Williams-Wang). For him this was another chance to use "China" for poetic restructuring and renewal, a chance to fulfill his dream of competing favorably against Pound and Fenollosa. If Williams's Chinese engagement during the 1910s and 1920s had facilitated his shift to a minimal, modernist style, the present enterprise would enable him to move away from the perpetual triad of

14. William Carlos Williams to Harriet Monroe, April 13, 1915, Joseph Regenstein Library, University of Chicago, quoted in Zhaoming Qian, Orientalism and Modernism: The Legacy of China in Pound and Williams (Durham, NC: Duke University Press, 1995), 115.

15. For "Complete Destruction," "The Red Wheelbarrow," and "The Locust Tree in Flower," see A. Walton Litz and Christopher MacGowan, eds., The Collected Poems of William Carlos Williams, vol. 1 (New York: New Directions, 1986), 159, 224, 379-80. Further references to this volume will be given parenthetically as $C P 1$. For a discussion of Williams's early exchanges with the Chinese, see Qian, Orientalism and Modernism, 113-41. 
his poetry since 1948, which he had once called a "solution of the problem of modern verse" but had now found "overdone, artificial, archaic." 16 The Chinese form was to contrast with the triad, a long line made up of three shorter, step-down units, as in Journey to Love (1955):

$$
\begin{aligned}
& \text { carrying a bunch of marigolds } \\
& \text { wrapped } \\
& \text { in an old newspaper: }
\end{aligned}
$$

and Paterson 5:

$$
\begin{aligned}
& \text { In old age } \\
& \text { the mind } \\
& \text { casts off }^{17}
\end{aligned}
$$

Personal interactions, however, proved both to assist and to complicate the appropriation project. At the outset, Williams's priority collided with Wang's. The old master privileged formal experiments over semantic accuracy, whereas the novice found it hard to accept arbitrary exclusion of cultural overtones. The first poet they worked on was Wang Wei (699759). As Williams recalled in a letter of February 25, 1958 (Rauner: Williams-Wang), Wang chanted to him the Chinese of two of the Tangdynasty poet's short lyrics and then jotted them down line by line, writing beneath them the meaning of the separate characters:

[Untitled]

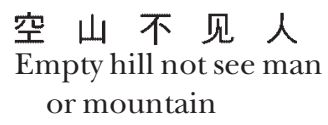

但闻人语响

But hear man's voice sound

\section{返 影入 深 林}

follow reflected light into deep woods

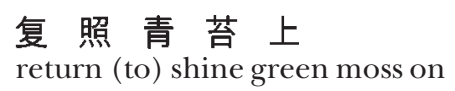

16. William Carlos Williams to John C. Thirlwall, June 13, 1955, in Selected Letters of William Carlos Williams, ed. John C. Thirlwall (New York: New Directions, 1957), 334; William Carlos Williams to Cid Corman, November 1, 1955, quoted in Paul Mariani, William Carlos Williams: A New World Naked (New York: McGraw-Hill, 1981), 689.

17. William Carlos Williams, Paterson, ed. Christopher MacGowan (New York: New Directions, 1992), 205. 


\section{送 别}

Farewell

山 中 相 送 罢

mountain (in the) see farewell end

日 暮 掩 柴 扉

the sun near evening close wooden gate

春 草 明 年 绿

spring grass next year green

\section{王孙归不归?}

young patrician return (or) not return.

(Beinecke: Wang-Williams, January 18, 1958)

The form in which the two poems were composed was not new to Williams. From Herbert A. Giles's History of Chinese Literature (1901), a book he owned and frequently cited, he surely had learned something about this form. ${ }^{18}$ Giles, who calls the Chinese quatrain "stop-short," illustrates its syllable counts in a paradigm:

\section{Sharp sharp flat flat sharp \\ Flat flat sharp sharp flat \\ Flat flat flat sharp sharp \\ Sharp sharp sharp flat flat}

"Although consisting of only twenty or twenty-eight words," according to Giles, the "stop-short" is "just long enough for the poet to introduce, to develop, to embellish, and to conclude his theme in accordance with certain established laws of composition." "The third line," he stresses, "is considered the most troublesome to produce, some poets even writing it first; the last line should contain a 'surprise' or dénouement." 19

In 1956 Williams told Edith Heal that during his early avant-garde phase he was often thrilled by restructuring his previously written poems in quatrains, tercets, and couplets. ${ }^{20}$ If Cubism provided him with the technique of fragmentation essential to such exercises, the Chinese gave him a pithy verse form to follow. As I have demonstrated elsewhere, Williams's "Complete Destruction" $(C P 1,159)$ consists of two quatrains, each resembling a "stop-short" in its syllable count. ${ }^{21}$ Even "The Red Wheelbar-

18. For an account of Williams's familiarity with Giles's History of Chinese Literature, see Qian, Orientalism and Modernism, 120-24.

19. Herbert A. Giles, A History of Chinese Literature (New York: Appleton, 1901), 144-46.

20. See William Carlos Williams, I Wanted to Write a Poem: The Autobiography of the Works of a Poet, ed. Edith Heal (Boston: Beacon, 1958), 65-66.

21. Qian, Orientalism and Modernism, 158-60. 
row" ( $C P 1,224)$ matches a "stop-short" with a slight deviation. Its eight lines can be seen as four lines each with a tag of a two-syllable word. Like a "stop-short," the first line, "so much depends / upon" introduces; the second line, "a red wheel / barrow," develops; the third line, "glazed with rain / water," embellishes; and the fourth line, "beside the white / chickens," concludes with a surprise.

On January 18, 1958, Williams returned to some of the formal concerns of this early phase in which he had played with the "stop-short" in terms of its minimal, spatial appearance. The versions he "stay[ed] up that late" to produce and sent to David Wang manifest in their own ways the physical properties of Wang Wei's short poems:
Empty now the hill's green
but the voice of a man refracted
from the deep woods livens
the green of the moss there.
Farewell
Farewell, the mountain watches as at evening I close the rustic gate spring grass will be green again tho' the young patrician return or no.

(Rauner: Williams-Wang)

The rectangular shapes of his versions distinctly take after the originals. The way the lines are divided, nevertheless, is reminiscent of Williams's practice from the mid-1910s to the 1930s. The recreation of Wang Wei's first "stop-short," in particular, brings to mind the opening of "Good Night," a 1916 lyric, which Marjorie Perloff identifies as Williams's early "experiment with the visual placement of words in lines."22

$$
\begin{aligned}
& \text { In brilliant gas light } \\
& \text { I turn the kitchen spigot } \\
& \text { and watch the water plash } \\
& \text { into the clean white sink. }
\end{aligned}
$$

$(C P 1,85)$

Both attempts are in three- and four-stress lines of predominantly monosyllabic words. Both contain lines broken in syntactically unnatural places. Just as in "Good Night," the third line is cut after the verb "plash" and before the prepositional phrase "into the clean white sink," so in Williams's version

22. Marjorie Perloff, “To Give a Design': Williams and the Visualization of Poetry,” in The Dance of the Intellect: Studies in the Poetry of the Pound Tradition (1985; repr., Evanston, IL: Northwestern University Press, 1996), 103. 
of Wang Wei's first "stop-short" the second line is severed after the past participle "refracted" and before its prepositional phrase "from the deep woods," and the third line is enjambed to separate the verb "livens" from its object "the green of the moss there." Such odd divisions of poetic lines, according to Perloff, are intended to make the visual objects "stand out, one by one, as in a series of film shots," or as in Picabia's drawings or Picasso's collages. $^{23}$

In theory, Williams's alertness to visual effects should ideally serve the purpose of rendering the painterly qualities of Wang Wei's minimal poems. In fact, Williams's design does help to unfold, in Wang Wei's fashion, his objects- "empty hills," "deep woods," and "green moss" in the first instance, and "mountain," "rustic gate," and "spring grass" in the second instance. However, Williams's version of the first "stop-short" has omitted "no man seen" and "light," thus eclipsing the odd pairings of no man/ voices and deep woods/light in the original. The odd pairings are meant to signify Zen illumination, with the unexpected human voices and the piercing sunlight symbolizing the sudden leap to enlightenment.

Wang Wei's "Farewell" recaptures a moment when an everyday sight (sunset) strikes a chord in the speaker's heart, reminding him of his sorrow over a friend's departure at sunrise. It similarly contains a minor shock: the certainty of spring grass's return contrasts with the uncertainty of ever having the company of his friend again. Williams does a better job of appropriating this poem. By juxtaposing "spring grass will be green again" and "the young patrician return or no," he roughly, if not wonderfully, reproduces that effect.

The role Williams played so far in the project is comparable to the role Pound played in the Cathay enterprise. He reworked Wang's draft versions as aggressively as Pound did Fenollosa's notes. Nevertheless, Williams's and Pound's partners were not of the same kind. While Fenollosa remained a silent literary source, Wang was an active participant. As such, he voiced his disapproval of Williams's version of the first poem: "I am afraid that you have changed the meaning too much" (Beinecke: WangWilliams, January 24, 1958). A note he enclosed drew attention to the suppressed details— "no trace of men" and "reflected light." Not surprisingly, Wang's criticism met resistance. Williams's revised version was another formal experiment at the cost of Chinese overtones. ${ }^{24}$ As a result, neither this nor the other Wang Wei quatrain appeared in "The Cassia Tree."

23. Ibid., 104.

24. Wang's note: "In the empty mountain with no traces of men, / I hear reverberation of human voices. / I follow the refracted light into the woods / And find it a spotlight on the green moss" (Beinecke: Wang-Williams, January 24, 1958). Williams's revised version: “Across the empty hills / in the deep woods / comes a man's voice / the green moss there" (Rauner: Williams-Wang, February 26, 1958). 
Ironically, the abandoned versions had aesthetic consequences. They paved the way for Williams's shift from the overused triadic pattern of Paterson 5 to the plain tercets and quatrains of his last volume. Peter Schmidt has demonstrated Williams's return to his early, minimal style in "Iris" $(C P 2,406)$ and other poems from Pictures from Brueghel. ${ }^{25}$ In Williams's last book we witness his renewed experiment with the "stopshort." Consider "The Chrysanthemum":

\author{
how shall we tell \\ the bright petals \\ from the sun in the \\ sky concentrically \\ crowding the branch \\ save that it yields \\ in its modesty \\ to that splendor?
}

$(C P 2,396)$

The poem recalls both Williams's "Complete Destruction" and his abandoned re-creations of Wang Wei. So do "Short Poem" and "Portrait of a Woman at Her Bath" (CP2, 416, 418). Between Paterson 5 and Pictures from Brueghel, Williams wrote several other minimal poems. "The Loving Dexterity" consists of two staggered quatrains (CP2, 348). "An Old-Fashioned German Christmas Card" and "Midwinter" both contain four tercets $(C P 2,354,358)$. These poems of 1958-60 are best viewed as Williams's further rehearsal of the style he initiated in the late 1910s. The Chinese re-creations, especially the two discarded versions of Wang Wei, really represent the old poet's first move away from his "overdone, artificial, archaic" triadic line.

David Wang's response to the license Williams was taking with Wang Wei's originals was ultimately to compromise. His goal was, after all, to study poetry writing with an old master. It would be necessary to surrender some Chinese ingredients. His tactic toward keeping this sacrifice down was to cater to Williams's tastes in the selection of Chinese poems. There would have to be a bit of give-and-take on both sides. Williams in turn was to give Wang a freer hand. To carry on the undertaking for experimental purposes, he had to keep his Chinese partner on board.

25. Peter Schmidt, William Carlos Williams, the Arts, and Literary Tradition (Baton Rouge: Louisiana State University Press, 1988), 243-44. See also Mariani, William Carlos Williams, 689 . 
The next piece selected was "The Lady of Lo-Yang," an early Wang Wei poem in the ballad mode, with few unfamiliar cultural overtones. When presenting it to Williams on January 27, 1958, Wang chose to withhold the original text and send only a draft version. In doing so he virtually took the manipulation of the form in hand. For this Chinese ballad in twenty seven-character lines with a rhyme scheme of $a a b a$, he substituted an unrhymed version in quatrains with five to seven beats to a line. As the English ballad stanza also consists of four lines, the choice of the quatrain, rectangular in shape, is appropriate.

The lady of Lo-Yang lives across the street.

By her looks she's about fifteen years of age.

Fitted with jade and silk her husband's horse is ready for parade.

In golden plates she is served sliced herring and caviar.

Her painted screen and roseate stairs rival in their hues.

The peach blossoms and willow shades spread outside her room.

Through gauze curtain she glides into her perfumed sedan chair.

'Midst feathery fans she enters her sequined mosquito net.

Her husband is a budding young, haughty millionaire;

His extravagance puts Mark Anthony even to shame.

Pitying her maids she teaches them the classic Chinese dance.

Tired of gifts she freely gives her corals and pearls away.

By her crystal screen she blows the light off her velvety lamp.

The green smoke rises like petals bourne upon the waves.

Filled with fun and laughter she has no regrets.

With her hair done up in a roll she sits by the candle case.

In her circle of friends are men of pedigree and wealth.

She visits only the king and aristocrats.

Can she recall the girl who was pure as ivory

And used to wash her clothings by the creek not very far away?

$(C P 2,501-2)$

This portrait of a Chinese wife had an appeal for Williams, the poet of "The Young Housewife" $(C P 1,57)$. Once he read Wang's draft version in an apt spatial form, he could not resist the temptation of rewriting it in more elegant English. The poem is an interested male's monologue about his affluent neighbor's wife. In Wang's draft the speaker has just a hint of a compassionate, conversational tone. Under Williams's care this quality is brought out:

Look, there goes the young lady across the street

She looks about fifteen, doesn't she? 
Her husband is riding the piebald horse

Her maids are scraping chopped fish from a gold plate.

$(C P 2,364)$

The interjection "Look," the rhetorical question, and the piled statements in present continuous tense all help to underscore the immediacy of the speaker's tribute to the lady of Lo-Yang.

The revised version continues in this fashion with more colloquial phrases, exclamations, midline pauses, and assertions in present continuous tense:

Her picture gallery and red pavilion stand face to face

The willow and the peach trees shadow her eaves

Look, she's coming thru the gauze curtains to get into her chaise:

Her attendants have started winnowing the fans.

Her husband got rich early in his life

A more arrogant man you never find around!

She keeps busy by teaching her maids to dance

She never regrets giving jewels away.

There goes the light by her window screen

The green smoke's rising like petals on wave

The day is done and what does she do?

Her hair tied up, she watches the incense fade.

and it concludes with the shocking revelation about the wife's family background:

None but the bigwigs visit her house

Only the Chaos and the Lees get by her guards

But do you realize this pretty girl

Used to beat her clothes at the river's head?

$(C P 2,364)$

Without any knowledge of the Chinese language Williams could not have detected certain misrepresentations in David Wang's version of the poem. For instance, where Wang Wei's speaker says "Day and night she goes past the gates of the Chaos and the Lees," Williams prompted by Wang has the speaker observe instead, "Only the Chaos and the Lees get by her guards" (line 18). Also, some of Wang Wei's sensual details reproduced in Wang's draft-say, the "jade" that decorates the husband's horse (line 3) and the "perfume" that fills the wife's chaise (line 7)-are omitted in the final version. But the overall picture and mood of Wang Wei's poem are recaptured. Whereas stanzas 1-3 closely follow David Wang's literal version-thus also the original-in delineating what the 
speaker has actually observed, in particular, the extravagant lifestyle of his neighbor's household, stanza 4 does so in bringing out what he has imagined, specifically the young wife's paradoxical emptiness of heart. As to Wang Wei's speaker's self-characterization, his contempt for the husband can be discerned in line 10: "A more arrogant man you never find around!" and his sympathy for the wife can be found in lines 19-20: "But do you realize this pretty girl / Used to beat her clothes at the river's head?"

From the revised version Wang no doubt learned one more facet of Williams's poetic, his rendering of American speech. Wang Wei's monoogue "The Lady of Lo-Yang," or "The Peerless Lady," should certainly be rendered in present-day American speech. Without Williams's changes, there would not be such an accessible and palatable final text. Notice that the colloquial phrase "The day is done" has replaced the conceptualized "Filled with fun and laughter" (line 16), and that the slang term "bigwigs" has filled in for the literal "men of pedigree and wealth" (line 17). Field singles out "bigwigs" as an example of the collaborators' use of the American idiom. ${ }^{26}$ It is Williams who has supplied the word, and he deserves credit for many more such colloquial phrases.

In February 1958 Williams felt that his health was again beginning to fluctuate. After two strokes he knew that he should not put too much pressure on himself, and he returned all of Wang's draft translations, thanking him for "hav[ing] come out to read to [him] the wonderful old language," and owning up to his defeat: "I have struggled with the poems but I cannot get a replica of the ancient language" (Rauner: Williams-Wang, February 25, 1958).

Wang, though, had not yet completed his lessons with Williams. He was understandably eager to continue to develop in conversation with Williams. In the next two and a half years, despite Williams's half-heartedness, he continued to send him version after version of Chinese poems. Along with these he also presented some original poems, including early cantos from his epic poem "The Grandfather Cycle." ${ }^{27}$ Williams reviewed most, if not all, of Wang's offerings, but only occasionally did he make comments or suggest revisions.

Speaking of a poem Wang had composed for the New Yorker, Williams advised him on April 14, 1958, "I do not think that a poem which does not have a single visual image in it would be of much interest to a New Yorker reader. If you are going to write that sort of poem it should have

26. Field, "Chinese Macropoem," 45n.

27. David Raphael Wang, "The Grandfather Cycle-an Epic Poem in Progress," The Human Voice 2 (1966): 31-36. Although Wang originally envisioned it as a long poem of 101 cantos, he only finished fifteen. 
at least the structural interest of a mathematical theorem" (Rauner: Williams-Wang). In reference to Wang's draft versions of Li Po (701-62), he recommended, "It is always a translation into the modern idiom of the old language. The edges must remain clear in the phrases you elect to use, never sentimental" (Rauner: Williams-Wang, May 12, 1958). Williams's emphases on the "structural interest" and the "modern idiom" set Wang on the right track for the project.

By midsummer 1958 Wang had moved to the West Coast to start working on a master's degree at San Francisco State College. On July 10, 1958, he wrote to inform Williams that he had attended Louis Zukofsky's poetry reading at the Art Museum. Enclosed was a version of a Li Po poem entitled "Spring Song":

\author{
A young lass \\ Plucks mulberry leaves by the stream. \\ Her white hand \\ Reaches toward the green. \\ Her rosy cheeks \\ Shine under the sun. \\ The hungry silkworms \\ Are waiting for her. \\ Oh, young horseman, \\ Why do you tarry? Get going!
}

$(C P 2,502)$

The version with images like "A young lass," "mulberry leaves," and "silkworms" should have reminded Williams of the Cathay piece "A Ballad of the Mulberry Road." 28 The original is Li Po's recreation of the Chinese ballad that had given rise to Pound's "The Mulberry Road." What is more likely to have impressed Williams, however, was the version's "structural interest." Its arrangement of the verse in five uneven couplets brings to mind Williams's early poems, such as "Nantucket":

Flowers through the window

lavender and yellow

changed by white curtains-

Smell of cleanliness-

28. Baechler and Litz, Personae, 144. Pound translated only the first fourteen lines of the fifty-three-line ballad. 


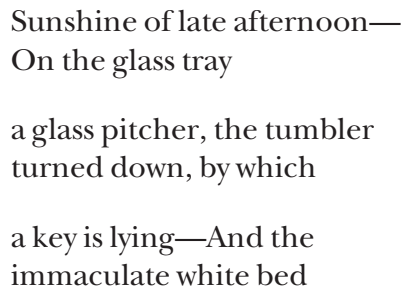

(CP1, 372)

Its short, oddly divided lines, like those of Williams's abandoned versions of Wang Wei, anticipate the plain (instead of step down) quatrains, tercets, and couplets of Pictures from Brueghel — as in "The Blue Jay":

\author{
It crouched \\ just before the take-off \\ caught \\ in the cinematograph- \\ ic motion \\ of the mind wings \\ just set to spread a \\ flash a \\ blue curse \\ a memory of you \\ my friend \\ shrieked at me \\ —serving art \\ as usual
}

$(C P 2,420)$

Li Po's original lyric certainly does not resemble any of these Williams poems. A regulated classic Chinese verse, it consists not of five couplets but of six lines with no stanzaic break or midline pause. From his mentor-collaborator, Wang had learned a way to force the reader's eye to key noun phrases and verb phrases by splitting one line into several and isolating them in a stanza. This he did with "Spring Song." After detaching Li Po's first two lines in a couplet, he cut each of the next four in two and arranged them in additional couplets. In dividing lines in this way, Williams would often violate American speech patterns in favor of the visual shape. So would Wang. Take Li Po's line 3, literally meaning "Her white 
hand on green leaves." In Wang's hands this line is turned into "Her white hand / Reaches toward the green." The line, now enjambed, breaks "Her white hand" and its movement "toward the green" into two distinct impressions. Consider also Li Po's last line alluding to an official in a fivehorse carriage, who made an offer of marriage. The allusion central to the original's theme is given up for spatial design. Further, what might be rendered as "Five horses, do not linger" is altered and expanded to "Oh, horseman / Why do you tarry? Get going." The shift from a voice directing a team of five horses to move to a voice urging a horseman to go, along with the enjambment and the strong caesura, clearly copied from Williams.

The emulation must have amused Williams, for he revised three lines and retyped the version for Wang. Inconspicuous as these revisions may appear, their effects are dramatic. If Williams's change of "by the stream" to "by the river" and modification of "toward the green" to "among the green" simply make lines 2 and 4 read better, his revision of "Her rosy cheeks" to "Her flushed cheeks" in line 5 at once avoids a cliché and strengthens an emotional coloring. Incidentally, Li Po's phrase, if literally rendered (as "rouged cheeks"), lacks this emotional resonance.

Williams's endorsement encouraged Wang to carry on his bold manipulation of line divisions in refashioning classic Chinese lyrics. On August 12, 1958, he sent Williams the result of another exercise, a version of a "stopshort" by Wang Chien (751-830) entitled "The Newlywed's Cuisine":

$$
\begin{aligned}
& \text { The third night after wedding } \\
& \text { I get near the stove. } \\
& \text { Rolling up my sleeves } \\
& \text { I make a fancy broth. } \\
& \text { Not knowing the taste } \\
& \text { of my mother-in-law, } \\
& \text { I try it first upon her } \\
& \text { youngest girl. }
\end{aligned}
$$

Notice the version's visual shape: four staggered couplets derived from the original's four short lines. Is this modeled on "The Red Wheelbarrow"? Notice also the separation of "of my mother-in-law" from "the taste" in stanza 3, which underscores a shock: three nights into her marriage, the bride is already left alone with her in-laws, trying to impress them instead of her groom. Williams, the inventor of such strategies, made no comment on this version. Nor did he meddle with Wang's other re-creations with peculiar line divisions. 
In the winter of 1959-60, Wang produced a version of a poem by $\mathrm{Tu}$ Fu (712-70). Through Kenneth Rexroth's One Hundred Poems from the Chinese, Williams had already sampled the brilliance of this poet. In a review of Rexroth's book for Poetry, he singled out three poems for praise, two of which were from the Chinese of Tu Fu. ${ }^{29}$ The Tu Fu poem he received from Wang on Christmas Eve 1959, "Portrait of a Lady," was about a woman from a good family who lost everything during the Tang civil war. Wang had done nothing drastic to Tu Fu's original composition except to break his twenty-four lines into six quatrains. Avoidable repetition and awkward insertion are visible in the opening quatrains:

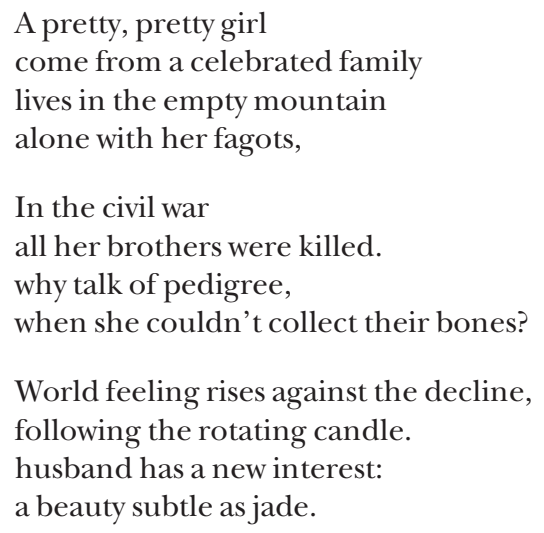

(Beinecke: Wang-Williams)

This poem by Tu Fu recalls Wang Wei's "Peerless Lady," Li Po's "Spring Song," and Wang Chien's "Newlywed's Cuisine," all sketches of medieval Chinese women that had appeal for Williams. In his edited version Williams renamed the poem "Profile of a Lady" (to avoid a too obvious borrowing from himself or T. S. Eliot), revised the opening stanza, and polished a line in the third stanza. In the revised opening stanza, he reversed the order of lines 2 and 3, changed "come" in what is now line 3 to "Came," and added "Now" before "alone with her fagots" in the final line $(C P 2,370)$. These revisions combine to underscore the contrast between the lady's pre-civil war life and post-civil war life, a contrast obscured in Wang's draft.

After a long silence in 1960, Wang wrote to Williams, "I would appreciate if I only get a card from you" (Beinecke: Wang-Williams, January 27, 1961). He was perhaps too polite to ask whether Mrs. Williams had ever

29. See William Carlos Williams, "Two New Books by Kenneth Rexroth," in Something to Say: Williams Carlos Williams on Younger Poets, ed. James E. B. Breslin (New York: New Directions, 1985), 236-46; Kenneth Rexroth, One Hundred Poems from the Chinese (New York: New Directions, 1956). 
read to Dr. Williams his letter of February 16, 1960, and an enclosed version of a Li Po poem entitled "A Letter," in which he had experimented with Paterson 5's triad:

\author{
My love, \\ When you were here there was \\ a hall of flowers.
}

(CP2, 364)

What Wang presented in this letter of January 27, 1961, was a version of another Li Po poem, "The Knight," which eventually appeared in "The Cassia Tree" collection without further revision. Similar to his earlier efforts, the twenty-six-line poem is broken into seven stanzas, with an opening quatrain distinguished by alliterations of $w$ 's and $b$ 's:

In March the dust of Tartary has swept over the capital.

Inside the city wall the people sigh and complain.

Under the bridge the water trickles with warm blood

And bales of white bones lean against one another.

$(C P 2,367)$

Wang was surely anxious to know what his mentor might think of the physical look of his version, in which quatrains mixed with sestets and couplets, and italicized lines blended with indented ones. He was, moreover, completing his MA that spring, ${ }^{30}$ and a year and a half later he obviously requested a letter of recommendation from Williams, to which Mrs. Williams responded, "I have taken care of the application-hope it is O.K. Bill is not in very good condition-is no longer writing and has great difficulty talking" (Rauner: Williams-Wang, August 12, 1962). Seven months later, Dr. Williams passed away at his Rutherford, New Jersey, home.

Although I have, to this point, highlighted the master/apprentice relationship between Williams and Wang, I want to conclude by stressing the dynamic of their collaboration. From Williams's revisionary suggestions, Wang surely learned a great deal about the handling of the poetic form in an effort to be modernist. By the early 1970s, he developed into a full-fledged Asian American poet and anthologist. ${ }^{31}$ Similarly, Williams

30. Wang received his PhD from the University of Southern California in 1972.

31. Wang went on to publish one of the first anthologies of Asian American literature, Asian-American Heritage: An Anthology of Prose and Poetry (New York: Washington Square Press, 1974). 
also learned from Wang. The younger poet's draft versions of Wang Wei and Li Po rekindled his passion for the minimal, painterly style of classic Chinese poetry and inspired him to take a new direction formally in his last book. Together the two poets created an English line of economy, understatement, and power.

I have been suggesting that "The Cassia Tree" is best understood in the context of transpacific "intertextual travel." Like Cathay, Yunte Huang's key example of this American literary practice, it mimics Chinese poetry only to boil it down "to a version that foregrounds the [collaborators'] own agenda." Just as Cathay makes Chinese poems appear more imagistic than they really are, "The Cassia Tree" moves the reader toward a spatial design that prefigured Williams's return to minimalism in Pictures from Brueghel. The dynamic of collaboration in this instance favored modernism. Indeed, the collection as a whole exhibits several hallmarks of Williams's middle years-his concern with American idiom, his interest in visual shape, and his tendency to subordinate the former to the latter. Wang's declaration that the American idiom is the series' guiding principle is misleading in that it oversimplifies the complexities of the re-creations involved. Although Williams insists that idiomatic language is his priority, he is willing to sacrifice the naturalness of his idiom to a degree to make his design attractive. Wang, as I have suggested, learned much from Williams about how to play idiom against visual design. Small wonder that despite his claim that "The Cassia Tree" poems are "re-creations in the American idiom," they do not always read like American speech. 